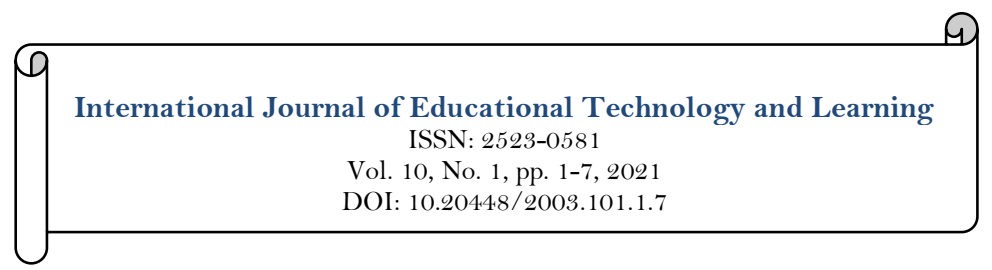

\title{
Powercoaching Program and Oral Discourse Competence of Grade 10 Students
}

\author{
Richard B. Sucion ${ }^{1}$ \\ Rebecca D. Subillaga ${ }^{2}$ \\ Cristobal M. Ambayon ${ }^{3 a}$
}

${ }^{\prime}$ New Pangasinan National High School, Isulan, Sultan Kudarat, Mindanao, Philippines.

-Instructor II, Sultan Kudarat State University, ACCESS, EJC Montilla, Tacurong City, Sultan Kudarat, Mindanao, Philippines.

${ }^{3}$ Asso. Professor $V$ and Corresponding Author, Sultan Kudarat State University, ACCESS, EJC Montilla, Tacurong City, Sultan Kudarat, Mindanao, Philippines.

Email:jophkris_01@yahoo.com

\begin{tabular}{|c|c|}
\hline Abstract & \\
\hline $\begin{array}{l}\text { Powercoaching is an intervention program which aims to enhance the oral } \\
\text { discourse competence of the students. It highlights various activities that can } \\
\text { help students with speaking difficulties. It was conducted among Grade } 10 \\
\text { students of New Pangasinan National High School during the School Tear } \\
\text { 2019-202O. This study dealt to determine the level of effectiveness of the } \\
\text { powercoaching program in terms of its content, relevance, instructional quality, } \\
\text { and acceptability. Experimental research design was employed to determine the } \\
\text { level of oral discourse competence of the students in terms of grammar, } \\
\text { pronunciation, spontaneity, substance, organization, and diction. The findings } \\
\text { of the study showed that the program was excellent and passed the quality } \\
\text { standard set by the validators. The level of oral discourse competence of the } \\
\text { students in their onset test were both in approaching proficient. The students } \\
\text { were either struggling or have not acquired the knowledge, skills and } \\
\text { understanding in public speaking. The difference between the levels of oral } \\
\text { discourse competence of the students reveals that among the two groups of } \\
\text { students, one group performed better in the outset test. The experimental group } \\
\text { significantly increased their performance with proficient level compared to the } \\
\text { control group. Moreover, there was a significant difference between the mean } \\
\text { gain scores of the control and experimental groups. Students under } \\
\text { experimental group have gained higher mean than the control group. Hence, } \\
\text { the powercoaching program greatly influenced the students oral } \\
\text { communicative competence. The developed program is then recommended for } \\
\text { teachers' utilization as part of their intervention strategies. }\end{array}$ & $\begin{array}{l}\text { Keywords: } \\
\text { Powercoaching } \\
\text { Intervention program } \\
\text { Oral Discourse competence. } \\
\text { Licensed: } \\
\text { This work is licensed under a } \\
\text { Creative Commons Attribution } 4.0 \\
\text { License. } \\
\text { Publisher: } \\
\text { Scientific Publishing Institute } \\
\text { Received: } 3 \text { December } 2020 \\
\text { Revised: } 23 \text { December } 2020 \\
\text { Accepted: } 6 \text { January } 2021 \\
\text { Published: } 21 \text { January } 2021 \\
\text { ( Corresponding Author) }\end{array}$ \\
\hline
\end{tabular}

Funding: This study received no specific financial support.

Competing Interests: The authors declare that they have no competing interests.

\section{Introduction}

Oral Communication skills are vital for students' academic success and future career preferences especially in an era dubbed the information age. In today's challenging environment, students must not only possess academic expertise, but also the requisite skills to enhance their learning and employability prospects in the future (Lucanus, 2017). Further, Griffin (2008) states that oral communication takes place in face-to-face conversations, group discussions, telephone calls, and other circumstances in which spoken words is used to express meaning. Through oral communication, students can communicate information and explore ideas and 
concepts; identify and solve problems; organize their experience and knowledge; express and clarify their thoughts, feelings, and opinions.

However, several studies have indicated that oral communication development has largely been neglected in the classroom, and most of the time, teachers always talk in the teaching and learning process than students. According to Dill (2009) anxiety and unwillingness during the English speaking process are considered two of the biggest obstacles for English as a Foreign Language (EFL) learners. Anxiety and unwillingness are caused by fear of being negatively evaluated when making mistakes particularly in front of their friends.

Nevertheless, Eric Digest (2000) as cited by Arzaga (2017) states that, many find oral communication as the most difficult skill to develop especially for learners whose language is taught only in the classroom. Most students encountered problems in speaking and expressing themselves in their oral discussions and experience stage fright, trembling when speaking, dryness of mouth and throat, poor eye contact, excessive perspiration, and mental block. These manifestations belong to the so called speech anxiety which affect students' social skills, self-esteem, and academic performance.

Such scenario is similar to the Grade 10 students of New Pangasinan National High School in every subject which requires English as a medium of communication. In a usual classroom discussion, it is evident among students that they are afraid to speak and answer in the discussion since they are very quiet when the teacher asks questions.

Thus, it is quite alarming to see these manifestations of speaking difficulties among Grade 10 students during English classes and even in other subjects. Considering that fifty percent of their grade covers performance tasks, they are expected to perform oral drills, oral presentations, oral reports, and recitations. If students cannot perform well in the oral activities and other related tasks, their grade will be affected and so is their total performance in school. This study therefore aims to develop an intervention program that would aid the students in overcoming their speech anxiety and in developing their oral discourse competence without any fear of expressing their thoughts in public.

\subsection{Statement of the Problem}

Generally, this study aimed to determine the effectiveness of the Powercoaching Program and Oral Discourse Competence of Grade 10 students.

Specifically, it sought to answer the following questions:

1. What is the level of effectiveness of the powercoaching program in terms of:
1.1. Content.
1.2. Relevance.
1.3. Instructional Quality.
1.4. Acceptability.

2. What is the onset level of oral discourse competence of the respondents in terms of:
2.1. Grammar.
2.2. Pronunciation.
2.3. Spontaneity.
2.4. Substance.
2.5. Organization and, Diction?

3. What is the outset level of oral discourse competence of the respondents in terms of:
2.6. Grammar.
2.7. Pronunciation.
2.8. Spontaneity.
2.9. Substance.
2.10. Organization.
2.11. Diction?

4. Is there a significant difference on the onset level of oral discourse competence of the control and experimental groups?

5. Is there a significant difference on the outset level of oral discourse competence of the control and experimental groups?

6. Is there a significant difference between the mean gained scores of the control and experimental groups in terms of students' oral discourse competence?

\section{Methods}

This study was conducted at New Pangasinan National High School in Isulan, Sultan Kudarat, Philippines.

\subsection{Research Design}

The experimental research designed was used to find out the effect of Powercoaching Program to the grade 10 students at New Pangasinan National High School. In this study, the control group underwent the 
usual type of their class in English subject following the prescribed curriculum and strategies used by the teacher. On the other hand, the experimental group underwent the intervention program prepared by the researchers themselves and validated by the panel of experts.

Prior to the implementation of the program, an onset test was administered to both experimental and control groups. Consequently, the experimental group was exposed to the powercoaching program as remediation in enhancing their oral communicative competence. After the duration of the program, an outset test was given to both groups.

\subsection{Respondents of the Study}

The respondents of the study were the grade 10 students of New Pangasinan National High School. There were 64 total number of students and all of them were included to take part in the study. The respondents were grouped into control and experimental groups. Since the sectioning of the school is heterogeneous in nature 33 students were selected as the control group while the 31 is in the experimental group.

The experimental group was taught by the researchers using an intervention program for three months, while the control group underwent the usual type of their class in English following the prescribed curriculum and strategies used by the teacher.

\subsection{Research Instrument}

The Powercoaching Program and Oral Discourse Competence was conducted during the School Year 2019-2020 at New Pangasinan National High School with grade 10 students as respondents. The instruments prepared for the gathering of data were as follows:

To evaluate the effectiveness of the Powercoaching Program, a validating instrument was rated by the panel of experts. They evaluated the intervention program in terms of content, relevance, instructional quality, and acceptability. A survey instrument was adapted from Herrera (2011)).

To evaluate the oral discourse competence of the respondents in the onset and outset test, there were four panel of experts who evaluated their performance using a modified rubric from Speakingwhiz (2008) with the indicators such as grammar, pronunciation, spontaneity, substance, organization, and diction.

\subsection{Data Gathering Procedure}

The researchers adapted a validating instrument from Herrera (2011) to evaluate the effectiveness of the program in terms of content, relevance, instructional quality, and acceptability.

Prior to the implementation of the program, an extemporaneous speaking was conducted to the control and experimental groups to evaluate their oral discourse competence.

To determine the onset and outset level of their performance, the rubric developed by Speakingwhiz (2008) was adapted by the researchers as their assessment tool. The series of questions during the onset and outset test were evaluated by the panel of experts along with the powercoaching program.

During the onset and outset test, each participant entered the hall one at a time, until after one participant finished his/her speech. The participants were required to prepare for speech on significant topics particularly youth issues. Possible subjects include but not limited to, drug addiction, teen pregnancy, gender discrimination, and leadership. Each participant were permitted to make notes during his/her preparation time. No electronic device was permitted in the preparation room. Participants picked their topics at fiveminute intervals and have not less than 10 minutes for preparation. No one is allowed to consult with the participant after they have selected a topic. Not less than 10 minutes after the selection of the topic, the participant delivered the speech. The question was stated in the exact words before the speech begins or as part of the speech. The participant handed the questions to the evaluators before the actual speech. Recommended length was two to three minutes. There was a timer device visible to the participant to guide his/her of the time.

The accomplished forms and data were collected and the results were analysed and interpreted.

\subsection{Statistical Treatment of Data}

The data was organized, tabulated, analysed and interpreted using the following statistical tools:

Mean was utilized to determine the level of effectiveness of the powercoaching program in terms of content, relevance, instructional quality, and acceptability. Mean was also used to evaluate the onset and outset level of oral communicative competence of the respondents in terms of grammar, pronunciation, spontaneity, substance, organization, and diction.

Further, z-test was used for the computation of the significant difference on the onset and outset levels of oral communicative competence of the control and experimental groups and the significant difference between the mean gained scores on the oral discourse competence of both groups. 


\section{Results}

Table-1. Summary of the grand mean ratings on the content, relevance, instructional quality and acceptability of the powercoaching program.

\begin{tabular}{c|c|c|c|c}
\hline Variables & Mean & SD & Description & Interpretation \\
\hline Content & 4.69 & 0.17 & $\begin{array}{l}\text { Excellent } \\
\text { quality standard }\end{array}$ & $\begin{array}{l}\text { Meets above 91-100\% } \\
\text { quality standard }\end{array}$ \\
\hline $\begin{array}{c}\text { Relevance } \\
\text { Quality }\end{array}$ & 4.56 & 0.38 & Excellent & $\begin{array}{l}\text { Meets above 91-100\% } \\
\text { quality standard }\end{array}$ \\
\hline $\begin{array}{c}\text { Acceptability } \\
\text { Onsuctional }\end{array}$ & 4.76 & 0.21 & $\begin{array}{l}\text { Meets above 91-100\% } \\
\text { quality standard }\end{array}$ \\
\hline Overall & 4.7 & 0.20 & Excellent & $\begin{array}{l}\text { Meets above 91-100\% } \\
\text { quality standard }\end{array}$ \\
\hline Source: Herrera (2011). & & 0.10 &
\end{tabular}

As presented in the Table 1, the summary of the grand mean ratings of the powercoaching program in terms of content, relevance, instructional quality, and acceptability resulted to a verbal description of excellent with an overall mean of $4.7(S D=0.10)$. This indicates that the overall mean ratings of the intervention program has passed the qualities expected by the trainer and the intervention program met the above quality standard.

The result of this findings is in accordance to the study of Bautista (2005) that teachers as professionals are expected to respond to any curriculum changes to make teaching and learning dynamic and effective. Thus, utilizing intervention program in oral communicative competence is one way by which the English teacher can achieve continuous development. The use of instructional material in English for instance, helps students become independent and self-directed learners and provides for new levels of individualization within the oral intervention program. Further, adequate instructional materials are excellent source of authentic language activities (Fernandez, 2010).

Table-2. Onset level of oral discourse competence of the control and experimental groups.

\begin{tabular}{c|c|c|c|c|c|c}
\hline Variables & \multicolumn{3}{c|}{ Control Group } & \multicolumn{3}{c}{ Experimental Group } \\
\hline Grammar & 1.67 & 0.54 & AP & 1.42 & 0.56 & $\mathrm{D}$ \\
\hline Pronunciation & 1.61 & 0.56 & AP & 1.58 & 0.67 & AP \\
\hline Spontaneity & 1.58 & 0.61 & AP & 1.52 & 0.63 & AP \\
\hline Substance & 1.61 & 0.61 & AP & 1.45 & 0.62 & $\mathrm{D}$ \\
\hline Organization & 1.55 & 0.56 & AP & 1.42 & 0.67 & D \\
\hline Diction & 1.52 & 0.57 & AP & 1.35 & 0.67 & D \\
\hline OVERALL & 9.52 & 3.10 & AP & 8.74 & 3.30 & AP \\
\hline
\end{tabular}

Source: Speakingwhiz (2008).

Legend: D- Developing, AP-Approaching Proficiency, P-Proficient, E- Excellent

Table 2 reveals the onset level of oral discourse competence of the control and experimental groups. The result of the onset test in the control group shows that the grammar $(\mathrm{M}=1.67, \mathrm{SD}=0.54)$ got the highest mean followed by substance $(\mathrm{M}=1.61, \mathrm{SD}=0.61)$; pronunciation $(\mathrm{M}=1.61, \mathrm{SD}=0.56)$; spontaneity $(\mathrm{M}=1.58$, $\mathrm{SD}=0.61)$; organization $(\mathrm{M}=1.55, \mathrm{SD}=0.56)$; while diction $(\mathrm{M}=1.52, \mathrm{SD}=0.57)$ got the lowest mean. Having a total scores of 9.52 ( $\mathrm{SD}=3.10$ ), it shows that their level of competence is Approaching Proficiency.

On the other hand, based on the result of the onset test in the experimental group, it shows that pronunciation $(\mathrm{M}=1.58, \mathrm{SD}=0.67)$ got the highest mean followed by spontaneity $(\mathrm{M}=1.52, \mathrm{SD}=0.63)$; substance $(\mathrm{M}=1.45, \mathrm{SD}=0.62)$; organization $(\mathrm{M}=1.42, \mathrm{SD}=0.67)$; grammar $(\mathrm{M}=1.42, \mathrm{SD}=0.56)$; while diction $(\mathrm{M}=1.35, \mathrm{SD}=0.55)$ got the lowest mean. Having a total scores of $8.74(\mathrm{SD}=3.30)$ it reveals that the level of their competence is Approaching Proficiency.

The result of the onset test simply means that the students in the control and experimental groups have a lower level of communicative competence. In a study conducted by Patil and Karekatti (2012) they stated that one of the primary elements found to be associated with poor communication skills development is known as communication apprehension or speech anxiety. During the actual speech delivery, the respondents were having difficulty in oral communication skills. It was evident among the respondents' reactions during the onset test that they were afraid to perform due to speech anxiety.

In the EFL setting, most learners develop oral communication apprehension or speech anxiety due to a lack of knowledge of vocabulary, grammatical structure, and pronunciation of the target language (Amogne \& Yigzaw, 2013). For example, a large number of EFL students do not dare to speak up or be involved in the conversational session because they regard themselves as weak in the target language. Similar situation happens during the onset test. Majority of the students in the control group experience the same. 
Therefore, teachers particularly in English might encourage the students to undergo remediation after their class focusing on grammar, pronunciation, spontaneity, substance, organization, and diction to improve the oral discourse competence of the students.

Table-3. Outset level of oral discourse competence of the control and experimental groups.

\begin{tabular}{l|c|c|c|c|c|c}
\hline Variables & \multicolumn{3}{|c|}{ Control Group } & \multicolumn{3}{c}{ Experimental Group } \\
\hline Grammar & 2.09 & 0.72 & $\mathrm{AP}$ & 2.42 & 0.72 & $\mathrm{AP}$ \\
\hline Pronunciation & 2.18 & 0.68 & $\mathrm{AP}$ & 2.52 & 0.68 & $\mathrm{P}$ \\
\hline Spontaneity & 2.12 & 0.86 & $\mathrm{AP}$ & 2.61 & 0.67 & $\mathrm{P}$ \\
\hline Substance & 2.21 & 0.86 & $\mathrm{AP}$ & 2.68 & 0.70 & $\mathrm{P}$ \\
\hline Organization & 2.06 & 0.79 & $\mathrm{AP}$ & 2.61 & 0.67 & $\mathrm{P}$ \\
\hline Diction & 2.00 & 0.79 & $\mathrm{AP}$ & 2.39 & 0.76 & $\mathrm{AP}$ \\
\hline OVERALL & 12.67 & 4.27 & $\mathrm{AP}$ & 15.23 & 3.95 & $\mathrm{P}$ \\
\hline
\end{tabular}

Source: Speakingwhiz (2008).

Legend: D- Developing, AP-Approaching Proficiency, P-Proficient, E- Excellent

Table 3 shows the result of the outset level of oral discourse competence of the control and experimental groups. Based on the result of the outset test of the control group, the substance got the highest mean $(M=2.21, S D=0.86)$; followed by pronunciation $(M=2.18, S D=0.68)$; spontaneity $(M=2.12, S D=0.86)$; grammar $(M=2.09, S D=0.72)$; organization $(M=2.06, S D=079)$; and the diction $(M=2.00, S D=0.79)$ which got the lower level of competence yet all the enumerated variables achieved. Having a total score of 12.67 with $(S D=4.27)$ it reveals that their level of competence is Approaching Proficiency.

While the result of the outset test of the experimental group shows that the substance $(M=2.68, S D=0.70)$ got the highest mean followed by spontaneity and organization $(M=2.61, S D=0.67)$; pronunciation $(M=2.52$, $S D=0.68)$; grammar $(M=2.42, S D=0.72)$; while diction $(M=2.39, S D=0.76)$ obtained a lower level of competence. Having a total score of $15.23(S D=3.95)$ with a verbal description of Proficient implies that the performance of the experimental group increased dramatically from its initial level compared to the latter. Further, the use of effective instructional materials and activities provides an interesting and compelling platforms in motivating the students to learn.

Further, this also supports the study of Henning, Mcintosh, Arnott, and Dodd (2010) when they examined the long-term outcomes of an oral language and phonological awareness intervention that aimed to improve the literacy outcomes of socially disadvantaged students. The intervention took place over 20 weeks and involved a trained teacher integrating an oral language component during lessons. The results comprehend that the literacy skills of intervention group students improved immediately after the intervention, with gains over and beyond the control group.

Table-4. Summary analysis of the onset levels of oral discourse competence of the control and experimental groups.

\begin{tabular}{c|c|c|c|c|c|c|c}
\hline Groups & $\mathbf{N}$ & Mean & SD & z-comp & df & p value & Interpretation \\
\hline Experimental & 31 & 8.74 & 3.30 & & & & \\
\hline & & & & .967 & 62 & .338 & not significant \\
\hline Control & 33 & 9.52 & 3.10 & & & & \\
\hline
\end{tabular}

Table 4 presents the summary analysis of the onset levels of oral discourse competence of the control and experimental groups. Since the computed $z$ is equal to .967 with a $p$ value of .338 result implies that there was an evidence not to reject the null hypothesis. The scores are comparable between the experimental $(M=8.74$, $S D=3.30)$ and control groups $(M=9.52, S D=3.10)$.

This further implies that the difference between the onset level of the control and experimental groups is due to chance. Furthermore, the onset level of the experimental group is almost the same level to that of the control group. This also infers that there was no intensive intervention strategy to improve their oral communication skills and the teachers need to conduct a remedial strategy. This findings is also similar to Raban (2000) research that learners need to be scaffold to new learning by someone who has greater control of the task, that is, a 'more knowledgeable other'.

Table-5. Summary analysis of the outset levels of oral discourse competence of the control and experimental groups

\begin{tabular}{c|c|c|c|c|c|c|c}
\hline Groups & N & Mean & SD & z-comp & df & p value & Interpretation \\
\hline Experimental & 31 & 15.23 & 3.95 & & & & Significant \\
\hline Control & & & & 2.485 & 62 & .016 & \\
\hline
\end{tabular}

Table 5 reveals the summary analysis of the outset level of oral discourse competence of the control and experimental groups. As reflected in the result, it shows that the computed $\approx$ is equal to 2.485 with a $p$ value of 
.016. It is evident that the null hypothesis is rejected. The scores of the experimental group $(M=15.23, S D=$ $3.95)$ is significantly higher than the scores of the control group $(M=12.67, S D=4.27)$.

Moreover, the difference between outset test levels of experimental and control group is greater than expected by chance. This further states that the achievement of the experimental group exceeds significantly than the control group and the experimental group performed well compared to the other in the outset level.

The result corroborates as well in a study conducted by Rowlands (2012) when he evaluated an oral language intervention that was tested with twelve preparatory students in two schools. The results of students' oral discourse competence appear that those who participated in the intervention made greater gains than students in the control group. However, students with the poorest literacy skills made the smallest gains, suggesting that alternative interventions may be more suitable for students with low-level literacy.

Table-6. Summary analysis on the mean gained scores of the control and experimental groups in terms of oral discourse competence.

\begin{tabular}{c|c|c|c|c|c|c|c}
\hline Groups & $\mathbf{N}$ & Mean & SD & z-comp & df & p value & Interpretation \\
\hline Experimental & 31 & 8.74 & 3.30 & & & & Not significant \\
\hline & & & & .967 & 62 & .338 & \\
\hline Control & 33 & 9.52 & 3.10 & & & & \\
\hline
\end{tabular}

Table 6 illustrates that the computed $z$ is equal to 4.193 with a $p$ value of $<0.0001$. This implies that there is a significant difference between the control and experimental group in their mean gains. Experimental group $((M=6.48, S D=2.99)$ is significantly higher compared to the control group $(M=3.15, S D=3.35)$.

The result of the study contradicts to Hill and Launder (2010) reported on teachers' experiences of using an oral language intervention aimed at improving the literacy skills of students in Year 1. The play-based intervention involved teachers incorporating oral language throughout their lessons and emphasizing oral language structures and vocabulary. Pre- and post-intervention assessments of students' literacy skills showed no significant gains in literacy. The authors concluded that oral language does not necessarily transfer to literacy skills.

\section{Conclusion}

In light of the foregoing findings, the following conclusions are drawn:

The Powercoaching program is an effective tool in enhancing the oral discourse competence of the students, as it rated excellently by the panel of validators and met the above quality standard in terms of its content, relevance, instructional quality, and acceptability.

Onset test result unveils that majority of the respondents were hesitant to speak in front of the audience since they are not confident in doing so. Lack of knowledge of vocabulary, grammatical structure, and pronunciation of the target language are among their concerns.

On the other hand, outset test shows that the performance of the experimental group rated as proficient is significantly higher compared to the control group. This manifests that after the intervention program the students in the experimental group somehow overcome their speech anxiety and developed their confidence in public speaking.

Further, study showed a significant improvement in the students' oral discourse competence by using the Powercaching Program, which focuses on grammar, pronunciation, spontaneity, substance, organization, and diction.

\section{Recommendations} offered:

On the basis of the summary of findings and conclusion drawn, the following recommendations are

1. The powercoaching program is highly recommended as an intervention to further enhance the oral communication skills of the Grade 10 students not only in New Pangasinan National High School (NPNHS) but for all high school students in the division of Sultan Kudarat and other neighbouring provinces in the region.

2. The teachers especially in English might utilized this powercoaching program as part of their remedial class or during summer class program to build self-confidence and overcome speech anxiety of the low performing students in every oral communication activities.

3. Sufficient information on the innovative and interactive activities must be provided to improve their love for speaking in both English and Filipino languages.

\section{References}

Amogne, D., \& Yigzaw, A. (2013). Oral communication apprehension, competence and performance among maritime engineering trainees. Journal of Media and Communication Studies, 5(1), 5-11.

Arzaga, M. (2017). Speech Anxiety and academic performance in oral communication in context among grade 11 students of polilio national high school: Basis for an oral intervention program. Lucena City: Manuel S. Enverga University Foundation. 
Bautista, R. (2005). Development of a module as an instructional material in teaching general Chemistry. Santiago City: University of La Salette.

Dill, Y. (2009). EFL Learners' communication obstacles. Electronic journal of Social Sciences, 8(29), 84-100.

Eric Digest. (2000). An individual's experience: A socio- cultural critique of communication apprehension research. Information Analyses; Journal Articles; Opinion Papers.

Fernandez, I. C. (2010). Intervention material in english grammar for seniors at tagudin national high school. Unpublished MSE Thesis. Ilocos Sur Polytechnic State College. Tagudin, Ilocos Sur.

Griffin, R. (2008). A first look at communication (5th ed.). Boston: McGraw Hill.

Henning, C., Mcintosh, B., Arnott, W., \& Dodd, B. (2010). Long-term outcome of oral language and phonological awareness intervention with socially disadvantaged preschoolers: The impact on language and literacy. Journal of Research in Reading, 33(3), 231-246.

Herrera, R. (2011). Development and validation of interactive computer aided instructional materials in English and student's performance. Unpublished Master's Thesis.

Hill, S., \& Launder, N. (2010). Oral language and beginning to read. Australian Journal of Language छ Literacy, 33(3), 240254.

Lucanus, A. (2017). Oral Communication skills are important for students. Retrieved from: https://collegepuzzle.stanford.edu/oral-communication-skills-are-important-for-students/. [Accessed August 6, 2019].

Patil, S., \& Karekatti, T. (2012). Correlation between level of communication apprehension and development of communication skills in engineering students. Lavel, Maharashtra, India: Gharda Institute of Technology.

Raban, B. (2000). Just the beginning. DETYA Research Fellowship Report No. 1. Canberra, ACT: Commonwealth of Australia.

Rowlands, S. M. (2012). How can oral language impact on literacy acquisition? The study of an oral language intervention program with preparatory students in Tasmania. Master's Thesis, University of Tasmania, Australia.

Speakingwhiz. (2008). iRubric: Oral communicative competence rubric. Retrieved from: https:/ / www.rcampus.com/rubricshowc.cfm? sp=true\&code=LX773W2. 